\title{
AN “UNEXOCENTRIC" SYNTHETIC ACCOUNT OF CUT-THROAT AND CHIMNEY SWEEP: EVIDENCE FROM POLISH
}

\begin{abstract}
A b stract. In English, exocentric compounds, such as chimney sweep and cut-throat do not possess an overtly expressed suffix. Instead, they seem to be composed of a verb and an argument of that verb, e.g. dare Vdevil $_{\mathrm{N}}$, shoe $_{\mathrm{N}}$ black $_{\mathrm{V}}$. Naturally, such an interpretation would immediately position the quoted examples among the representatives of root compounding.

We are convinced that zero derivation plays a significant role in the formation of English synthetic compounds in the same way it is seen in Polish. We believe that the research material from Polish offers a substantial amount of evidence for the active participation of conversion in the process of synthetic compounding. This, in turn, accentuates the need to revisit the classification of such formations as spoilsport and chimney sweep, habitually classified as exocentric.

This paper provides an 'unexocentric' synthetic account of N-V/V-N compound nouns in English. We believe that a root interpretation of shoeblack and daredevil types does not reflect their genuine structure, which, as we argue, rests on a combination of a nominal and verbal stems followed by a zero affix, being the locus of morphosyntactic features and the semantic referent.

In our analysis, we draw on a revised version of LIH, i.e. Lieber and Scalise's (2007) Firewall Theory, which belongs to the current of the so-called mixed models of word-formation advanced in the recent years by, for instance, Ackema and Neeleman (2004), Lieber and Scalise (2007), and Pafel (2017), allowing for a limited intermodular interaction between morphological and syntactic domains.
\end{abstract}

Key words: exocentric; synthetic compounds; (paradigmatic) conversion; left-branching structure.

JoAnna Kolbusz-Buda, PhD - Siedlce University of Natural Sciences and Humanities, Faculty of Humanities, Institute of Polish Studies and Foreign Languages; address for correspondence — e-mail: joanna.kolbusz-buda@uph.edu.pl 


\section{INTRODUCTION}

In English, exocentric compounds such as chimney sweep and cut-throat do not comprise an overtly expressed suffix. Instead, they seem to be composed of a verb and an argument of that verb, e.g. dare devil $_{\mathrm{N}}$, shoe $_{\mathrm{N}}$ black $_{\mathrm{V}}$. Naturally, such an interpretation would immediately position the quoted examples among the representatives of root compounding.

Except for Marchand (11-12), who does not exclude a structural analogy between watch-maker and pickpocket, English linguistic literature keeps the two word-formation types apart, interpreting the former as endocentric and synthetic while the latter as exocentric and root. Although Marchand does not further elaborate this issue, we are convinced that zero derivation plays a significant role in the formation of English synthetic compounds in the same way we see it operate in Polish. We believe that the research material from Polish offers a substantial amount of evidence for the active participation of conversion in the process of synthetic compounding. This, in turn, accentuates the need to revisit the classification of such formations as spoilsport and chimney sweep, habitually classified as exocentric.

In what follows, we wish to propose an "unexocentric" synthetic account of N-V/V-N compound nouns in English. We believe that a root interpretation of shoeblack and daredevil types does not reflect their genuine structure, which, as we argue, rests on a combination of nominal and verbal stems followed by a zero affix - the locus of morphosyntactic features and the semantic referent.

In our analysis, we draw on a revised version of the Lexical Integrity Hypothesis, i.e. Lieber and Scalise's (18-23) Firewall Theory, which belongs to the current of the so-called mixed models of word-formation advanced in the recent years by, for instance, Ackema and Neeleman, Lieber and Scalise, and Pafel. The Firewall Theory allows for a limited intermodular interaction of morphological and syntactic domains.

\section{SYNTHETIC VS ROOT COMPOUNDS}

Traditionally, when defining the morphological nature of a synthetic compound, the anglophone literature reaches for such terms as lexeme (Bauer, "Compounding" 695) and word (Marchand 11). Though the mentioned terminology works well for analytic languages, it is hardly accurate 
for Polish, Czech, Slovak, or Russian, which fall into the category of synthetic languages. In Polish, a highly inflected tongue, composition rests on roots, rather than fully-fledged words: prac-o-daw-ca 'employer' < praca 'work' (N) + dawać 'give' (V) + -ca (Af). Polish compounds are inflected for case, number and gender. We will prove that it is the inflectional layer that brings to light those aspects of compoundhood that have not yet been uncovered for analysis. This, in turn, may allow to deepen the understanding of the syntheticity of compounding in a cross-linguistic perspective and revisit the morphological structure of chimney sweep and cut-throat, so far classified as exocentric.

Canonically, a synthetic compound is considered a two-lexeme unit whose rightmost component is a deverbal noun: brick-[[lay $\left.]_{\mathrm{V}}-e r\right]_{\mathrm{N}}$. Such understanding of syntheticity implies a right-branching morphological structure: [brick [layer]]. An in-depth analysis of the Polish material compels us to remodel the definition of a synthetic compound currently in force and formulate it as a two-step process of root compounding (not necessarily verbal) subjected to suffixation: [[sok $\left.\left.k_{\mathrm{N}}-o-w y z \dot{z} m a c z_{\mathrm{V}}\right]-k a_{\mathrm{Af}}\right]$ 'juice extractor', [[bos $\left.\left.\mathrm{A}^{-}-\boldsymbol{-}-n o \dot{z}_{\mathrm{N}}\right]-k a_{\mathrm{Af}}\right]$ 'bare-foot dancer'. As for root compounds, such as church yard, they are often defined as combinations of two lexemes, the latter of which, serving a dual function of the morphosyntactic and semantic head, is not a deverbal noun.

Interestingly, the analysis of the Polish data indicates that a traditional binary division into root and synthetic compounds may not be sufficiently clear-cut as among the representatives of Polish synthetic compounds there is a large group of formations whose right-hand lexical component is a synthetically created non-deverbal noun. This noun may either be a free-standing word in the Polish lexicon or an unrecorded lexical unit, formed solely for the purpose of a given compound. By way of illustration, consider cases of synthetic composition in Polish. Following Wiese (253), we represent the ordering of components as A (root 1), B (root 2), and C (derivational affix): 
Table1.

\begin{tabular}{|c|c|c|}
\hline N-V-Af - [ABC] & $N-V>V-[A B]$ & V-Af $>N-[B C]$ \\
\hline $\begin{array}{l}\text { sok-o-wyżymacz-ka } \\
\text { juice-interfix-extract-Af } \\
\text { 'juice extractor' }\end{array}$ & *sokowyżymać & $\begin{array}{l}\text { wyżymaczka } \\
\text { 'extractor' }\end{array}$ \\
\hline $\begin{array}{l}\text { jadł-o-daj-nia } \\
\text { food-interfix-give-Af } \\
\text { 'eating house' }\end{array}$ & *jadłodać & *dajnia \\
\hline $\begin{array}{l}\text { padlin-o-żer-ca 'scavenger' } \\
\text { waste-interfix-devour-Af }\end{array}$ & *padlinożreć & *żerca \\
\hline $\begin{array}{l}\text { dom-o-krąż-ca } \\
\text { house-interfix-roam-Af } \\
\text { 'canvasser' }\end{array}$ & *domokrążyć & *krq̨żca \\
\hline V-N-Af - [BAC] & $\mathbf{V}-\mathbf{N}>\mathbf{N}-[\mathrm{BA}]$ & $N-A f>N-[A C]$ \\
\hline $\begin{array}{l}\text { wyrw-i-racz-ka } \\
\text { rip out-interfix-hand-Af } \\
\text { 'surface lift' }\end{array}$ & ${ }^{*}$ wyrwirącz & $\begin{array}{l}\text { raczka } \\
\text { 'little hand' }\end{array}$ \\
\hline $\begin{array}{l}\text { baw-i-dam-ek } \\
\text { entertain-interfix-ladies-Af } \\
\text { 'ladies' man' }\end{array}$ & *bawidam & *damek \\
\hline $\begin{array}{l}\text { gryz-i-piór-ek } \\
\text { bite-interfix-pen-Af } \\
\text { 'pen-pusher' }\end{array}$ & ?gryzipiór & *piórek \\
\hline
\end{tabular}

As can be seen from the above, both structures, notwithstanding the reversed ordering of roots, represent the same word-formation type (Kurzowa 25; Kolbusz-Buda, Compounding 91-94; Złożenia 40). It is worth noting that neither a left nor a right-branching interpretation guarantees that either of the sequences $[\mathrm{AB}],[\mathrm{BA}],[\mathrm{BC}],[\mathrm{AC}]$ will give rise to a free-standing word.

\section{THE QUESTION OF BRANCHING}

To resolve the issue of morphological dependency within the structure of a synthetic compound, one should analyse the interrelations that hold between the A, B, C components. Those scholars who consider $\mathrm{C}$ an integral part of B, postulate a right-branching structure (see Selkirk; Di Sciullo and 
Williams; Booij “The Relation”; Lieber Deconstructing Morphology; Morphology and Lexical Semantics; "English Word-Formation"). According to this line of thinking, the union of $\mathrm{B}$ and $\mathrm{C}$ takes precedence over $\mathrm{B}$ and $\mathrm{A}$ : [book [[sell] [-er]]]. Others, seeing $\mathrm{A}$ and $\mathrm{C}$ as arguments of the verb, emphasise that the verb should first combine with the internal argument, which largely coincides with the direct object. As a result, we speak of a leftbranching structure with an internal root compound subjected to suffixation where the external argument " $C$ " gets coindexed with the verb "B" once the internal argument "A" has been coupled with it: [[[truck] [drive ]] -er] (see Lieber "Argument Linking"; Fabb; Sproat; Ackema and Neeleman; Lieber and Scalise; Booij "Lexical Integrity"; Kolbusz-Buda Compounding; Złożenia).

Interestingly, the major criticism against the left-branching interpretation of synthetic compounds is not the order of binding arguments, which, in our opinion, ought to be the main criterion for determining the morphological structure, but a non-existent form of the internal verb $[\mathrm{AB}]:{ }^{*}$ truckdrive. It should be stressed that the $[\mathrm{AB}]$ component is merely a substrate rather than the final product of compounding. Moreover, the very fact of the absence of $[\mathrm{AB}]$ does not imply that the sequence of [BC] is invariably a free-standing lexeme. On the contrary, there is a large number of Polish deverbal synthetic compounds whose $[\mathrm{BC}]$ as well as $[\mathrm{AC}]$ components are unrecorded nouns (see Table 1).

Furthermore, it is often the case that a synthetically formed [BC] (alternatively $[\mathrm{AC}]$ ) component, being part of a synthetic compound structure, is not consistent with the semantics of a parallel free-standing noun. Both nouns, though convergent in a structural dimension, are not congruent denotationally and should thus be considered mere homophones. To illustrate, the $[\mathrm{AC}]$ murek in obszczymurek 'drunkard, lit. the one who pees on the wall' coincides with a diminutive form of the noun mur 'wall', i.e. murek 'little wall'. The synthetically formed murek is the locus of both the internal and external arguments of the verb szczeć 'pee', namely Agent expressed by the suffix -ek, and Patient realised by the noun mur 'wall'. Hence, the argument raised by the proponents of the right-branching structure against the $[[\mathrm{AB}] \mathrm{C}]$ interpretation of synthetic compounds who focus on the absence of the $[\mathrm{AB}]$ component turns out to be a double-edged weapon. We have seen that either of the sequences $[\mathrm{AB}],[\mathrm{BA}],[\mathrm{BC}],[\mathrm{AC}]$ in Polish may be (1) an absent lexical unit or (2) a homophone of an already existing syntactic category. 


\section{ARGUMENT BINDING}

Canonically, in a synthetic compound, whose structure rests on a verb, the $\mathrm{A}$ and $\mathrm{C}$ components constitute the locus of the internal and external arguments of that verb. ${ }^{1}$ The formal exponent of composition - the derivational suffix - is the external argument which corresponds to the subject of the underlying clause revealed in a paraphrase. In Polish, the internal argument may be located in either the left- or right-hand root: $c h l e b_{\mathrm{N}^{-}}-d a w-c a$ 'employer, lit. bread-give-Af' vs $w y r w-i-r q c z_{\mathrm{N}}-k a^{2}$ 'surface lift, lit. rip outhand-Af'. As for the external argument, it may take the shape of both a derivational suffix and a morphological zero (the exponent of paradigmatic conversion): (ABC) chleb-o-daw-ca 'employer, lit. the one (-ca) who gives bread,' (BAC) wyrw-i-racz-ka 'surface lift, lit. the thing $(-k a)$ that rips out the hand,' (ABC) grot-o-taz- $\varnothing$ 'potholer, lit. the one $(-\varnothing)$ who roams the caves', (BAC) czyśc-i-but- $\varnothing$ 'shoeblack, lit. the one $(-\varnothing)$ who cleans shoes'.

In light of the above, the right-branching interpretation of structure would allow the verb to coindex first with its external argument (see the [ABC] ordering of components) or, in the case of [BAC] ordering, to enclose both arguments of the verb in a single lexical unit: (ABC) [dom-o-[kraż-ca]] 'canvasser', [piorun-o-[chron-Ø]] 'lightning conductor' vs (BAC) [gryz-i[piór-ek]] 'pen-pusher', [gol-i-[broda-Ø]] 'barber'. In both cases, the verb would become separated from its closest argument. The results of the present study refute the above hypothesis.

Another objection raised against the left-branching structure is an alleged violation of the key principle of lexicalism, namely the No-Phrase Constraint, originally formulated by Botha (18). Under such an interpretation, the internal root compound would be classified as a verb phrase subjected to suffixation: truck driver $<\left[[\text { drive trucks }]_{\mathrm{VP}}-e r\right]_{\mathrm{N}}$, and consequently judged as ill-formed. However, data collected from a wide range of languages seem to undermine the dogmatism of the constraint. Lieber and Scalise (4-12), Bisetto and Scalise (32-42), Kolbusz-Buda (Złożenia 30-39), among others, quote numerous examples from languages such as English, Italian, Quechua,

\footnotetext{
${ }^{1}$ See Lieber (Morphology and Lexical Semantics 61) who spells out a mechanism of argument coindexation (linking) within a word-structure, adapted by Kolbusz-Buda (Compounding 99).

${ }^{2}$ The stem racz-in wyrwirqczka is an alternant of the basic stem form ręk- representing the noun ręka 'hand.'

${ }^{3}-c a$ is an agentive suffix whereas $-k a$ and $-e k$ may derive both Agents and Instruments in Polish.
} 
Japanese, Spanish, Dutch, and Polish which unambiguously point to phrasal derivation. ${ }^{4}$

The wealth of accumulated data inspired Lieber and Scalise design a theory allowing for a limited interaction of the morphological and syntactic domains in the field of word-formation. Despite the fact that the syntactic module by its very nature cannot look into morphology (and vice versa), the so-called "Morphological Merge can select on a language-specific basis to merge with a phrasal/ sentential unit" (Lieber and Scalise 21). This phrasal unit is subsequently downgraded to the category of a word via the process of grammaticalisation. As a result, in the same way that syntax builds on morphology, morphology may build on syntactic constructions, though the interplay is highly constrained.

\section{THE RELEVANCE OF THE MORPHOLOGICAL STRUCTURE FOR EXOCENTRICITY}

Relying on Kolbusz-Buda's (Compounding; Złożenia) research findings in the field of Polish compounding, we argue that proper classification of a compound word as endo- or exocentric is primarily dependent upon the type of its morphological structure, i.e. the type of branching. Studies in Polish compounding point at a frequent co-occurrence of the left-branching structure and conversion, where the zero affix becomes not only the locus of morphosyntactic features but, more importantly, the semantic head (e.g. $\left[\left[\text { gol }_{\mathrm{V}}-i-b r o d a_{\mathrm{N}}\right]-\varnothing\right]_{\mathrm{N}}$ 'barber', [[grot $\left.\left.\mathrm{N}_{\mathrm{N}}-\mathrm{-}-\mathrm{taz}_{\mathrm{V}}\right]-\varnothing\right]_{\mathrm{N}}$ 'potholer'). We believe this correlation can be generalised to the English V-N cut-throat and N-V chimney sweep.

A standard definition of a root compound assumes that the right-hand lexeme is both a morphological and semantic head. However, if the righthand component is not the hypernym of the compound, the semantic head is believed to be located outside its morphological structure (see Bloomfield 235; Bauer, English Word-Formation 30, "Les Composés Exocentriques" 35-36). It is worth noting that in the absence of an overtly expressed semantic head, which in the case of cut-throat and chimney sweep types invariably coincides with the semantic role of Agent (the one who cuts throats, the one who sweeps chimneys), it is only natural that the formation will be subsumed

\footnotetext{
${ }^{4}$ In this regard, we refer the reader to the observations made by the above-quoted authors.
} 
under the category of exocentric if the concept of a three-component morphological structure (chimney sweep $_{\mathrm{B}} \varnothing_{\mathrm{C}}$, cut $_{\mathrm{B}}$-throat ${ }_{\mathrm{A}}-\emptyset_{\mathrm{C}}$ ) is disregarded.

In what follows, we want to argue that when the right-hand lexeme of a deverbal compound cannot be considered the referent, the function of the semantic head will be taken over by the morphological zero. Additionally, as discussed in the following section, the zero affix, will become the locus of morphosyntactic features. In this way, the same morpheme will serve the role of both grammatical and semantic heads, and the whole structure will be subsumed under the category of a synthetic compound.

\section{PARADIGMATIC CONVERSION IN POLISH - RELEVANCE FOR ENGLISH}

In the Polish linguistic literature, the term paradigmatic conversion is used to refer to a suffixless word-formation process in which the difference between the input and output forms boils down to a difference in their inflectional paradigms. In practice, paradigmatic conversion may take the shape of an unmarked change of the word-class in which case the input and the output share the same stem: piorun-o-chron-Ø 'lightning conductor' $<$ chro-

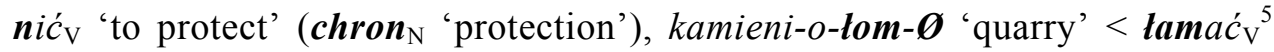
'to break' $\left(\boldsymbol{t a m}_{\mathrm{N}}\right.$ 'a break').

In inflected languages, such as Polish, where the word-external morpheme may perform more than one grammatical function, conversion becomes a multidimensional process, leaving its imprint not only on the syntactic category but, more importantly, on the morphosyntactic layer. An example of such a feature modification can be a shift in grammatical gender of the output word with respect to the input category with a simultaneous preservation of the wordclass: $u c h o_{\mathrm{N}}$ 'ear' (neut.) $>$ ktapouch $_{\mathrm{N}}$ 'lop-eared creature' (masc.), pióro $\mathrm{N}_{\mathrm{N}}$

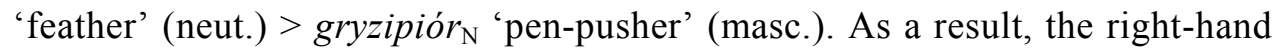
nominal root, having undergone a shift in the grammatical gender, is moved to a different declension paradigm. This type of conversion operates among the representatives of the suffixless $\mathrm{V}-\mathrm{N}-\varnothing$ compound type.

The change of the declension paradigm is, however, not obligatory under Polish conversion. Interestingly, despite retaining all the morphosyntactic features of the base, except for the grammatical gender, the compound may

\footnotetext{
${ }^{5}$ The morphemes -ić and -ać in chronić and łamać are the infinitive endings.
} 
pair with a demonstrative pronoun, a modifying adjective or a verb incongruent with the gender specification of the right-hand nominal root. Consider examples taken from the National Corpus of the Polish Language. ${ }^{6}$ Please note that despite communicating the masculine gender, the synthetic compound invariably retains the feminine declension pattern:

(1a) $t a_{\text {Det:fem. }} m o r d a_{\text {N:fem. }}$ 'this mouth; mug' vs

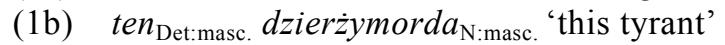

(1c) znany $_{\text {Adj:masc. }}$ dzierżymorda $a_{\mathrm{N}: \text { masc. }}$ przyjechat ${ }_{\mathrm{V}: m a s c .}$

'a well-known tyrant came'

(2a) $t a_{\text {Det:fem. }} w o d a_{\mathrm{N}: \text { fem. }}$ 'this water' vs

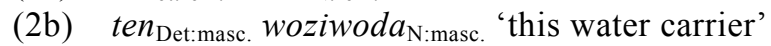

(2c) nadjechat V:masc. oczekiwany $_{\text {Adj:masc. }}$ woziwoda $_{\mathrm{N}: m a s c .}$

'the awaited water carrier arrived'

(3a) $t a_{\text {Det:fem. }} d u d a_{\mathrm{N}: f e m}$. 'this pipe' vs

(3b) $t e n_{\text {Det:masc. }}$ dlawiduda $a_{\mathrm{N}: m a s c .}$ 'this organist'

(3c) ten $_{\text {Det:masc. }}$ dlawiduda $a_{\mathrm{N} \text { :masc. }}$ od Bernardynów, co chodzit $\mathrm{V}_{\mathrm{V} \text { masc }} z$ nami na obiady 'that organist from Bernardines who went to dinner with us'

(4a) $t a_{\text {Det:fem. }} b r o d a_{\mathrm{N}: f e m}$ ' $t$ this beard' vs

(4b) ten $_{\text {Det:masc. }}$ golibroda $a_{\mathrm{N}: m a s c .}$ 'this barber'

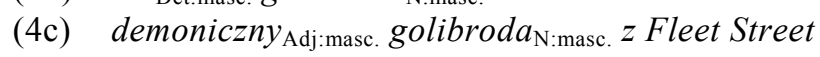
'the diabolic barber from Fleet Street'

All things considered, conversion in Polish synthetic compounding may be accomplished in three ways: (1) through a change of a word-class

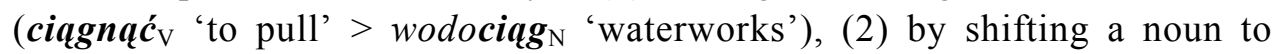
a declension paradigm representing a different grammatical gender while retaining the syntactic category of the input word (ucho $\boldsymbol{N}_{\mathrm{N}}$ 'ear' (neut.) > klapouch $_{\mathrm{N}}$ 'lop-eared creature' (masc.)), (3) or through communicating a referent whose grammatical gender is incongruent with the gender specification encoded in the paradigm of the right-hand nominal root with a simultaneous preservation of the declension type ( $\boldsymbol{t a}_{\mathrm{fem}} \boldsymbol{b r o d a _ { \mathrm { fem } } .}$ vs $\boldsymbol{t e n} \boldsymbol{n}_{\text {masc. }}$ golibroda $_{\text {masc. }}{ }^{7}$ ). In view of the above, neither of the quoted types of conversion allows us to interpret the right-hand root (be it a verb or a noun) as the formal exponent of compounding for its morphosyntactic properties are not congruent with the morphosyntactic features of the compound. Therefore, the

\footnotetext{
${ }^{6}$ Narodowy Korpus Języka Polsiego (NKJP), http://nkjp.pl/poliqarp.

${ }^{7}$ Although golibroda communicates masculine gender, it follows the feminine paradigm.
} 
role of the grammatical head is taken over by an additional morpheme - the exponent of conversion - validated by the presence of the morphosyntactic features encoded in the compound but uncharacteristic of the right-hand root.

\section{SYNTHETIC DEVERBAL COMPOUND NOUNS IN ENGLISH}

In what follows, we will take a closer look at two morphological variants of the same word-formation type represented by cut-throat (V-N-Ø) and chimney sweep $(\mathrm{N}-\mathrm{V}-\varnothing)$, being counterparts of Polish czyśc-i-but- $\varnothing(\mathrm{V}-\mathrm{N}-\varnothing)$ and grot-o-taz-Ø $(\mathrm{N}-\mathrm{V}-\varnothing)$, classified as synthetic by, for instance, Kurzowa $(20-30)^{8}$ and Kolbusz-Buda (Compounding 46, Złożenia 22-23).

\subsection{V-N-Ø cut-throat and N-V-Ø chimney sweep}

The type cut-throat is fundamentally a Romance type which arose under the influence of French after the Norman Conquest. The compound is a combination of a verb and a noun. The verb-direct object syntactic relations that hold between the two lexemes are brought to the surface in a paraphrase: cut-throat 'the one who cuts throats'. Compounds such as cut-throat, daredevil, pickpocket, turncoat, spoilsport, killjoy, wagtail, breakwater have no overt head. Moreover, the right-hand lexeme cannot be considered the superordinate element. As a result, it has been argued that the referent of the discussed type lies outside the compound's structure and therefore should be classified as exocentric.

Since English is a word-based language in which, unlike in Polish word formation system, a shift in grammatical gender does not operate, overlooking the actual (i.e. synthetic) morphological structure should come as no surprise. In stem-based Polish, a morphological zero is far more tangible, as conversion often brings about various types of modification of the morphosyntactic features. This, in turn, validates the presence of a compound-external zero morpheme. In contrast, in English, the mechanism of the morphosyntactic feature percolation will be confined to two parameters: number and syntactic category. ${ }^{9}$ In con-

\footnotetext{
${ }^{8}$ Please note that despite the fact that Kurzowa does not use the term synthetic nor does she juxtapose Polish compound types with the corresponding English types, she does point to conversion as a factor in the process of Polish compounding.

${ }^{9}$ See Lieber (Deconstructing Morphology 91) who develops a theory of morphosyntactic feature percolation from the head morpheme to the highest-level dominating node. Lieber argues
} 
sequence, the presence of $-\varnothing$ will be far more conspicuous in $\mathrm{N}-\mathrm{V}-\varnothing$ chimney sweep than in $\mathrm{V}-\mathrm{N}-\varnothing$ cut-throat.

Chimney sweep is a 'mirror image' of the Romance type ${ }^{10}$ and a carbon copy of Polish N-V-Ø grot-o-taz- $\varnothing$ 'potholer' that rests on a left-hand noun followed by a deverbal noun. Unlike in V-N-Ø cut-throat, whose right-hand nominal component could easily be interpreted as the source of morphosyntactic features, i.e. the head, the presence of the morphological zero in $\mathrm{N}-\mathrm{V}-\varnothing$ structure is much more palpable as the syntactic category of the compound is not congruent with the category of the right hand lexeme: $\mathrm{N} \neq \mathrm{V}$. Naturally, the verb cannot be responsible for transmitting the morphosyntactic specification, such as number and syntactic category to the highestlevel dominating node. These morphosyntactic features are assigned by way of $\mathrm{V}>\mathrm{N}$ conversion whose formal exponent is the morphological zero. This, in turn, proves the active participation of conversion in constructing the morphological scaffolding of a synthetic compound (see section 1 and 5 for analogical examples from Polish).

It is worth noting that the leftmost lexeme functions as the direct object of the verb in the syntactic input construction. The verb constitutes the head of the internal root compound and is responsible for discharging arguments in the underlying syntactic construction which are inherited by the nominal root (the internal argument) and the head affix (the external argument). The zero affix serves the role of both the grammatical and semantic head as it is the locus of inflexion and the argument structure: chimney sweep - the one (Agent) who sweeps chimneys (Theme).

\section{CONCLUSIONS}

By virtue of structural similarity with Polish synthetic compounds, such as gryz $_{\mathrm{V}}-i-$ piór $_{\mathrm{N}}-\varnothing$ 'pen-pusher, lit. bite-feather', czys' $c_{\mathrm{V}}-i-b u t_{\mathrm{N}}-\varnothing$ 'shoeblack,

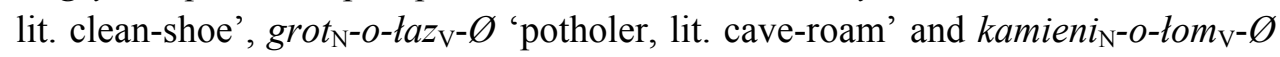
'quarry, lit. stone-break', we argue that N-V chimney sweep and V-N cutthroat compound types, so far primarily classified as exocentric and root, are in

\footnotetext{
that the process of percolation and the inheritance of the argument structure in words take place via separate mechanisms.

${ }^{10}$ Other representatives of the N-V-Ø type are, for instance, shoeblack, moneygrab, doorstop, billfold, woodcut, foothold.
} 
fact synthetic $\mathrm{V}-\mathrm{N}-\varnothing / \mathrm{N}-\mathrm{V}-\varnothing$ formations whose structure rests on an internal root compound subjected to zero derivation.

The research material from Polish provides evidence for the active participation of conversion in certain types of synthetic compounding through highlighting the presence of the compound-external morphosyntactic functions and simultaneous absence of a morphological form in which these features would be contained. The types of conversion which operate in Polish compounding bring to light significant morphological facts which due to the syntheticanalytic character of the English language could go unnoticed.

In Polish, not only do we observe a change of the compound's syntactic category with respect to its right-hand verbal root (lekorób $b_{\mathrm{N}}$ 'pharmacist' < robić $_{\mathrm{V}}$ 'make', koniokrad $_{\mathrm{N}}$ 'rustler' < kraść $\mathrm{V}_{\mathrm{V}}$ 'steal'), which is the essence of the English conversion ( shoeblack $_{\mathrm{N}}<$ black $_{\mathrm{V}}$, chimney sweep $_{\mathrm{N}}<$ sweep $_{\mathrm{V}}$ ), but also a shift in the grammatical gender coinciding with either a paradigm

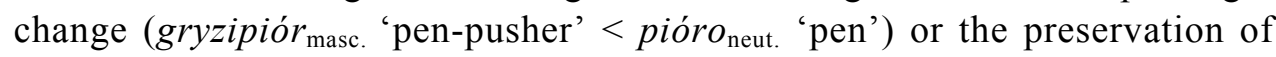
the declension type with a simultaneous change of gender ( $m o r d a_{\text {fem. }}$ 'mouth;

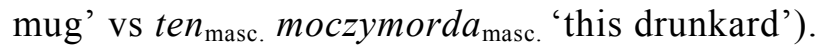

Since it has been substantiated that synthetic compounds may possess a morphosyntactic head in the form of a morphological zero, it does not seem justified to uphold an exocentric interpretation of those formations which show signs of conversion as an accompanying word-formation process. We have seen that the compound-final morphological zero can be filled with a semantic content, namely the external argument of the verb, thereby enclosing all the semantic variables within the morphological premises of the compound.

In the light of the above research findings, we want to argue that $\mathrm{V}-\mathrm{N}-\varnothing$ cut-throat and N-V-Ø chimney sweep should receive an "unexocentric" interpretation as neither the morphosyntactic nor the semantic head of both morphological types is "exo" with respect to the compound's structure. Consequently, the terms exocentric and synthetic should be regarded as mutually exclusive (despite the fact that the former pertains to the semantic level while the latter to the area of morphological analysis) as long as the head of a synthetic compound, be it overtly or non-overtly expressed, constitutes its hypernym. 


\section{WORKS CITED}

Ackema, Peter, and Ad Neeleman. Beyond Morphology: Interface Conditions on Word Formation. Oxford UP, 2004.

Bauer, Laurie. English Word-Formation. Cambridge UP, 1983.

Bauer, Laurie. "Compounding." Language Universals and Language Typology, edited by Martin Haspelmath, Ekkehard König, Wolfgang Oesterreicher, and Wulf Raible. De Gruyter, 2001, pp. 695-707.

Bauer, Laurie. "Les Composés Exocentriques de l'Anglais." La Composition dans une Perspective Typologique, edited by Dany Amiot. Artois Presses Université, 2008, pp. 35-47.

Bloomfield, Leonard. Language. Allen and Unwin, 1933.

Botha, Rudolf. "A Base Rule Theory of Afrikaans Synthetic Compounding." The Scope of Lexical Rules, edited by Michael Moortgat, Harry van der Hulst, and Teun Hoekstra. Foris Publications, 1981, pp. 1-77.

Bisetto, Antonietta, and Sergio Scalise. "Compounding: Morphology and/or syntax?" Boundaries of Morphology and Syntax, edited by Lunella Mereu. John Benjamins, 1999, pp. 31-48.

Booij, Geert. "The Relation between Inheritance and Argument Linking: Deverbal Nouns in Dutch." Morphology and Modularity: to Honour Henk Schultink, edited by Arnold Evers, Riny Huybregts, and Mieke Trommelen. Foris Publications, 1988, pp. 57-73.

Booij, Geert. "Lexical Integrity as a Formal Universal: A Constructionist View." Universals of Language Today, edited by Sergio Scalise, Elisabetta Magni, and Antonietta Bisetto. Springer, 2009, pp. 83-100.

Di Sciullo, Anna, and Edwin Williams. On the Definition of Word. MIT Press, 1987.

Fabb, Nigel. Syntactic Affixation. PhD Dissertation. MIT Press, 1984.

Kolbusz-Buda, Joanna. Compounding in Polish and English. A Morpho-Semantic Analysis of Synthetic Deverbal Compound Nouns in Polish in the Light of Parallel Constructions in English. Wydawnictwo KUL, 2014.

Kolbusz-Buda, Joanna. Złożenia Syntetyczne w Języku Polskim. Analiza Formalna. Wydawnictwo Uniwersytetu Przyrodniczo-Humanistycznego, 2019.

Kurzowa, Zofia. Złożenia imienne we współczesnym języku polskim. PWN, 1976.

Lieber, Rochelle. "Argument Linking and Compounds in English.” Linguistic Inquiry 14, 1983, pp. 251-86.

Lieber, Rochelle. Deconstructing Morphology: Word Formation in Syntactic Theory. University of Chicago Press, 1992.

Lieber, Rochelle. Morphology and Lexical Semantics. Cambridge UP, 2004.

Lieber, Rochelle. "English Word-Formation Processes." Handbook of Word-Formation, Studies in Natural Language and Linguistic Theory 64, edited by Pavol Štekauer and Rochelle Lieber. Springer, 2005, pp. 375-422.

Lieber, Rochelle, and Sergio Scalise. "The Lexical Integrity Hypothesis in a New Theoretical Universe." On-line Proceedings of the Fifth Mediterranean Morphology Meeting, edited by Geert Booij, Bernardo Fradin, Emiliano Guevara, Angelo Ralli, and Sergio Scalise, 2007, pp. 1-24. https: \\geertbooij.files.wordpress.com/2014/02/mmm5-proceedings.pdf. Accessed 13 June 2019.

Marchand, Hans. The Categories and Types of Present-Day English Word Formation. a Synchronic-Diachronic Approach. Beck, 1969.

Pafel, Jürgen. "Phrasal Compounds and the Morphology-Syntax Relation." Further Investigations into the Nature of Phrasal Compounding, edited by Carola Trips and Jaklin Kornfilt, Language Science Press, 2017, pp. 233-259. 
Selkirk, Elizabeth. The Syntax of Words. MIT Press, 1982.

Sproat, Richard. On Deriving the Lexicon. PhD Dissertation. MIT, 1985.

Wiese, Richard. "A Two-Level Approach to Morphological Structure." Journal of Germanic Linguistics 20, 2008, pp. 243-274.

\section{ENDOCENTRYCZNA INTERPRETACJA WYRAZÓW ZŁOŻONYCH TYPU CUT-THROAT I CHIMNEY SWEEP W JĘZYKU ANGIELSKIM NA TLE POLSKIEJ KOMPOZYCJI}

\section{Streszczenie}

W języku angielskim wyrazy złożone typu chimney sweep „kominiarz” i cut-throat „nożownik" nie mają materialnie wyrażonych sufiksów. Wydają się być raczej zbudowane z czasownika i argumentu tegoż czasownika, np. dare ${ }_{\mathrm{V}}$ devil $_{\mathrm{N}}$,,ryzykant”, shoe ${ }_{\mathrm{N}}$ black $_{\mathrm{V}}$, pucybut”. Naturalnie, taka interpretacja pozycjonuje cytowane typy złożeń wśród reprezentantów kompozycji rdzeniowej (root compounding).

Jesteśmy zdania, iż derywacja zerowa odgrywa ważną rolę w procesie kompozycji syntetycznej w języku angielskim podobnie jak ma to miejsce w języku polskim. Język polski dostarcza licznych dowodów na aktywny udział konwersji w tworzeniu syntetycznych złożeń właściwych. Wyrażamy nadzieję, iż analiza polskiego materiału językowego pozwoli ukazać potencjał derywacji zerowej w świetle kompozycji oraz zaakcentować potrzebę ponownej analizy budowy morfologicznej angielskich wyrazów złożonych typu spoilsport i chimney sweep, zwyczajowo klasyfikowanych jako egzocentryczne i rdzeniowe.

W niniejszym artykule prezentujemy „nieegzocentryczną” syntetyczną interpretację angielskich wyrazów złożonych typu N-V i V-N. W naszej ocenie, uznanie spoilsport i chimney sweep za złożenia rdzeniowe nie odzwierciedla ich faktycznej struktury morfologicznej, która - jak dowodzimy - opiera się na kombinacji rzeczownika i czasownika poddanych afiksacji zerowej. Jak wykazuje analiza, to właśnie zero morfologiczne jest członem w którym lokują się cechy morfoskładniowe oraz referent całej formacji.

W naszej analizie posiłkujemy się jedną z wersji teorii leksykalizmu, zaproponowaną przez Lieber i Scalise (2007), tzw. Teorią Zapory (Firewall Theory), zaliczaną w morfologii w poczet tak zwanych teorii mieszanych, która pozwala na ograniczony stopień interakcji modułów morfologii i składni w procesach słowotwórczych.

Słowa kluczowe: egzocentryczność; złożenia syntetyczne; konwersja (paradygmatyczna); struktura lewostronnie rozgałęziona. 